\title{
Increasing Students' Participation Through Cooperative Learning Method: A Case of Bonga University first Year Biology Students
}

\author{
Wondimu Huluka ${ }^{1 *} \quad$ Banteamlak Habtamu ${ }^{2}$ \\ Department of Biology, College of Natural and Computation sciences, Bonga University, Bonga Ethiopia
}

\begin{abstract}
Education is a process of facilitating learning or acquisition of knowledge, skills, values, belief and habits. It is bases for development and empowerment for every nation. Cooperative learning is a set of methods in which students work together in small groups and help one another to achieve learning objectives ${ }^{\circ}$ (Johnson \& Johnson, 2009). It is well recognized as a pedagogical practice that promotes learning, higher level thinking, pro social behavior, and a greater understanding of children with diverse learning, social and adjustment needs (Cohen 1994). The general objective of the study is increasing first year Biology Department Students' participation in cooperative learning methods (in collaborative group work). To conduct this study, both qualitative and quantitative research methods were employed. The quantitative data was collected from 44 Biology first year students. Qualitative data was collected through observation and focus group discussion from all students. The primary data were collected through observation and questionnaire from first year biology students. The secondary type of data also collected from related research works, documents at different line, students' achievement in the previous semester from department and social interaction changes. In the selection of the sample population, available sampling was employed. The data was analyzed by using percentage, and frequencies. The finding of the study revealed that students participation was low in cooperative learning and the practice of Cooperative learning was challenged by different problem like lack of awareness and motivation both in the side of teachers and students, dependence of lower achievers on higher achievers, unequal sharing of work among group members, inappropriate group organization, uncomfortable seating arrangement of students, and insufficient support and follow up from teachers. Nevertheless, by utilizing the proposed actions like creating awareness about the importance of cooperative learning, reorganizing group arrangement, providing different responsibilities for each member of the group and providing the required support for all the groups the researchers observed improvement on achievement of students. Thus, it is possible to conclude that, cooperative learning can improve the participation of students if it is conducted in well-organized way by using different strategies that help learners to take responsibility by themselves.
\end{abstract}

Keywords: Cooperative learning, Participation, Collaborative Learning, action plan/intervention

DOI: $10.7176 / \mathrm{JEP} / 11-13-05$

Publication date:May $31^{\text {st }} 2020$

\section{Introduction}

Education is a process of facilitating learning or acquisition of knowledge, skills, values, belief and habits. It a bases for development and empowerment for every nation and plays vital role in bringing socio-cultural, economical, technological, political and environmental advancements. However, to achieve these goals or to attain quality education, the teaching learning process at all educational institutions should be supported by strong two way communications (teacher -students or student's - students) meaning active participation had better observed during the whole course provision sessions (Major and Palmer, 2001).

Learning is generally defined as cognitive change, that is, some addition to a learner's knowledge structures or reorganization and reconstruction of that learner's existing knowledge. This change occurs as connections is made between new material and prior knowledge and then integrated into the learner's existing knowledge base. According to socio-cognitive learning theory (Mugny \& Doise, 1978, Vygotsky 1978), cognitive change is strongly influenced by interaction and activity with others. Because of this reason, today various College and university students are increasingly being asked by faculty to work co-operatively and learn collaboratively.

Researchers have shown that group learning leads to academic and cognitive benefits. Group learning promotes student learning and achievement (Cockrell et al. 2000; Hiltz 1998; Johnson et al.2000; Slavin 1992), increase the development of critical thinking skills (Brandon and Hollingshead 1999; Cockrell et al. 2000 as sited in Sisay awgichew et al,,2015). Group learning also aids in the development of social skills such as communication, presentation, problem solving, leadership, delegation and organization (Cheng and Warren 2000) as cited by (Robyn M. Gillies and Adrian F. Ashman, 2003). According to (Sewnet Tesfaye and Kassegn Berhanu, 2015) about $75 \%$ of the students assured that group discussion gives them more chance to participate freely in the class than demonstrations and presentations.

Students learn best when learning is active: When they are mentally involved, when they engage in hands-on 
activities, when they are involved in a process of inquiry, discovery, investigation, and interpretation. Thus, learning is enhanced when students repeat the information in their own words or when they give examples or make use of the information (Bransford, Brown, and Cocking, 2000).

When students are passive, their brain doesn't do job of processing effectively or retaining the information efficiently (Biggs, 1999; Hartley, 2005). This study is undertaken to assess actively participation of first year Biology students of Bonga University and thereby to improve their participation in cooperative learning method.

In Ethiopia, even if the government takes different measures to achieve a better goal in education system; there are different challenges that face education in the universities. Among them the basic one is that our students are inactive in the classroom. Thus there is a strong need to create active and responsible citizens that could participate in achieving core objectives. Here, because of this we need to improve the participation of students by creating different mechanisms.

\subsection{Statement of the Problem}

In today's world; Education has been transformed as to be a means for achieving ones' own need and this can be accomplished by implementing active learning. In the earlier times students are considered as to be an empty poet that the teacher will fill knowledge by lecture method without an active involvement of students in the classroom i.e. by considering students as passive learners, so that they have no room for participation and discussion in the classroom. In contrast, there is a constructivist approach for learning that students should have to play great role for their own learning and take a responsibility, if so education will be very interesting and fruitful (Yosef Kasa, 2016). Cooperative learning is an approach to group work that minimizes the occurrence of those unpleasant situations and maximizes the learning and satisfaction that result from working on a high-performance team. Thus, we have to use cooperative learning methods so that students will interact with their environment and discuss with their colleagues.

Currently, the Ministry of Education (MOE) is advocating cooperative learning approach in all schools, colleges and universities. But in case of Bonga University even if it we are using some active learning methods, students are very passive to participate in the classroom. This can be due to different factors like problem of language, awareness of teachers to use active teaching methods is low, students' perception about education is very low, students' motivation in participation is low, etc. Now we are interested to solve this problem so that our students will be active participant in class and out of class in their cooperative group activities that will contribute for development of students' knowledge as well as for the overall development of our country. Therefore, the researchers designed the following basic questions to investigate the problems and made proper intervention to improve student's participation; this action study was answers the following basic questions:

1. What is the level of students' participation?

2. Why students' participation becomes low in cooperative learning?

3. What are the factors affecting students' participation in collaborative learning, presentations and demonstrations?

4. What are the possible solutions for challenges which hamper students not to take part in cooperative work actively?

5. How can we implement so as to increase the involvement of students in cooperative learning?

\subsection{General objective}

The general objective of the study is increasing active participation of first year Biology Department Students' in cooperative learning method (Collaborative group work, Reflection and Demonstrations).

\subsubsection{Specific objectives of the Study}

The specific objectives of the study are.

1. To evaluate the level of participation of students in the classroom.

2. To identify factor affecting students' participation in collaborative group work.

3. To take action or intervention as to improve students contribution in cooperative learning activities

\section{Materials and Methods \\ 2.1 Target Group}

The target groups of this research are first year Biology students which are 44 in number.

\subsection{Research Design}

The study was both qualitative and quantitative type of research, because both numerical and non-numerical data were collected during the study by observation and questionnaire with the students in the classroom.

\subsection{Sample size Determination and Sampling Techniques}

Census sampling was used as recommended by most scholars that if the total number of study population is less 
than 100 , it is advisable to use all study population as a whole. Therefore the total 44 of first year Biology students were participated.

\subsection{Type and Source of Data}

The study used both primary and secondary data. The sources of primary data for this study are basically fist year Biology students of Bonga University and secondary data was collected from related research works, documents at different line, students' achievement in the previous semester from department and social interaction changes. For observation, the researcher themselves are instructors of Biology department so that they have observed in their normal teaching learning sessions.

\subsection{Data collection procedure}

The researchers informed both the college and the department about the issues and also research group make clear the idea for the student to engage freely to the project. From the beginning of data collection to the intervention action made by teachers in the classroom to improve the participation of student's information was accountably communicated. The required data was collected both from primary and secondary sources. The primary data sources were students, through questionnaires, direct observations of the real situations related to the practices of cooperative learning process in the classroom and Focus group discussion with Biology department Students. In addition to primary data, secondary data was collected from related research works, documents at different line, students' achievement in the previous semester from department and social interaction changes.

\subsection{Methods of Data Analysis}

The researchers analyzed quantitative data through percentage and frequency. Percentage was utilized to analyze and determine different characteristics and personal back ground of the respondent, the frequency was utilized to analyze and describe the degree to which cooperative learning affect student participation.

The data obtained through observation and focus group discussion were analyzed using narrative description (qualitative methods of analysis). The data collected from primary and secondary sources was tallied, tabulated and analyzed through descriptive statistical tools and descriptive narrations to analysis the data that was gathered from the focus group discussion.

\subsection{Results and Interpretation}

This part of the paper has two sections. Section one deal with the background information of respondents while section two deals with the overall result of the analysis of the issue under investigation (views of respondents about cooperative learning)

In Table 1 from 44 questionnaires dispatched to students, 90.9\% (40) questionnaire were filled properly and returned. Therefore, the analysis part presents the data obtained from these 40 students. Regarding the sex of students, $22(55 \%)$ were females and the remaining $18(45 \%)$ were males. In terms of age, 37(92.5\%) of the respondents were between 19 and 24 and $3(7.5 \%)$ of the respondents were between 25 and 29 . This indicates that, the respondents were matured enough to understand and fill the questionnaire dispatched to them.

From the table-2, for item one $62.5 \%$ of respondents had chosen scale number , $5^{\mathrm{c}}$ which indicates the largest response for this particular question. Vast majority of the students have interest in cooperative learning. This also showed that the prevalence of gap in some extent on students knowledge about cooperative learning, even though majority $67.5 \%$ of the responded that students have knowledge/ understanding on cooperative learning.

The second item of the questioner was designed to collect information on ,Students participation in cooperative learning ${ }^{e}$. As indicated on the table: $20 \% \& 15 \%$ participant responds low \& very low participation respectively, and $37.5 \%$ indicated high participation. This indicated that still significant numbers of students are reluctant to participate in cooperative learning.

The role of cooperative learning in improving social interaction among students is one of the questions presented for participant students. Even though significant number i.e. $57.5 \%$ of the respondents scaled very high and $20 \%$ respondents scaled high, some $2.5 \%$ of respondents scaled low and $10 \%$ of respondents scaled very low. This indicated that there is no uniformity among students about the role and importance of cooperative learning in social interactions among students.

Another important question is about Students awareness of cooperative learning practices ${ }^{e}$. As indicated in the table 2 below, $35 \%$ and $15 \%$ participants scaled very high \& high respectively, and $5 \%$ and $2.5 \%$ of participants responds low and very low respectively. This indicates that still significant number of students did not have aware about cooperative learning. Even though, majority of students have good understanding and better awareness on cooperative learning: There is no uniformity of understanding among students about cooperative learning, Some students are reluctant or not fully participated in cooperative learning, there is a gap in practicing cooperative learning among students in the classroom, Significant number of students did not aware clearly what cooperative learning is and the implication is that there is the need for awareness rising program for the students in the 
classroom to help all learners have common understanding of cooperative learning among all students.

As indicated in table-3 below, most of the indicated factors are highly affecting the participation of students in cooperative learning in general. Among all, unequal sharing of work among group members $(55 \%)$, lack of students' motivation to work in groups (47.5\%), relating cooperative learning with politics $(47.5 \%)$ and problem of grouping/ Organization structure (40\%) are highly affecting the participation of students in active learning.

In similar manner, Uncomfortable seating arrangement of students (35\% Domination of some group members (32.2\%) Shortage of time given by instructors to deal with the given issue (30\%), lack of students awareness about the benefits of cooperative learning $(20 \%)$, Lack of teachers motivation to use cooperative learning $(20 \%)$ and Lack of reinforcement by teachers $(20 \%)$ are affecting the participation of students in active learning even if their effect is a little bit lower than those identified earlier.

\section{Action plan, Implementation and Evaluation}

When we are conducting this action research, the researchers developed strategies that clearly identified the role of teacher and the role of the students. The teacher's role in active learning is fundamentally different from that in a more traditional model. It is vital that the teacher first provides the supportive classroom ethos to encourage active learning and opportunities for team building. Alongside this is the necessity for developing interpersonal skills as part of a planned program. The teacher play indispensable roles for the success of the program among the fundamental roles undertake by the teachers see the following action plan table. The role of the student's in cooperative learning is different from traditional classrooms is the inclusion of cooperative student-to-student interaction over subject matter as an integral part of the learning process.

\subsection{Implementation of the Action Plan}

Activity: 1- Creating Awareness about cooperative Learning for Students

Lack of awareness about cooperative learning was one of the major factors affecting the participation of students in cooperative learning and hence it has been one of the causes for low achievement of students in the department of Biology. As a result, awareness creation discussion was held with students for one period ( 2 hours).

Activity: 2- Re-organize and Re-structuring the group

Since group arrangement of students was found to be one of the factors affecting cooperative learning, reorganization of groups was conducted based on the first semester continuous assessments of students. After this, the research team members developed a model that enhance cooperative learning environment by providing responsibility for each and every member of the group as indicated here under.

Leader: a group leader provides direction, instructions and guidance to a group of individuals, for achieving a certain goal.

Facilitator: A facilitator of a group helps group members to understand their common objectives and assists them to plan how to achieve these objectives; in doing so, the facilitator remains "neutral" meaning he/she does not take a particular position in the discussion. Responsible for getting the group started, keeping it on task, and involving all members.

Note taker: a student who takes notes during cooperative learning activities or group discussion

Reporter: a student who is responsible for summarizing group decisions for the larger class

Time keeper: a student who is responsible for keeping group on task and on time particularly with in-class and other activities

Observer: a student who pays close attention to cooperative learning activities or group activities

Activity: 3. Monitoring and assisting each group members as needed after providing the task to be performed. The instructor started to provide task to be done in cooperative learning groups based on the above newly arranged grouping system. In doing so, the instructors also provided all the necessary support as needed by all group members as much as possible. The instructor conducted this activity for almost two months.

Activity: 4. evaluating the performance of each group's

To evaluate the performance of each group the instructor used one technique. That was by observing the number of students who participate and try to answer the questions raised by the instructor while the instructor is rotating around all groups to provide feedback.

\subsection{Action Evaluation}

After intervention had take place, the research team evaluate what change occurred. Some of the major changes that have been observed are briefly presented as follows;

After two hours training and interactive discussion with Biology department students about their awareness towards cooperative learning methods 35 (79.5\%), of student's rate their awareness about cooperative learning is high and the rest $9(20.5 \%)$ rate their awareness about cooperative learning is medium.

1. Re-organize and Re-structuring of the group: After rearranging their group almost all students become 
interested and asked the instructors in order to have continuity for other courses to be taken in the next semester. Beyond this re-organization of group members also provided an additional opportunity for students to create and strengthen their social life with new members of the group.

2. Providing different roles: Regarding the provision of a specific task for every member of the group most students $(>90 \%)$ agreed that it enhanced their feeling of responsibility for their task as it mandates every student to participate in cooperative learning.

At the end of taking all the actions discussed above the research team observed considerable improvement on student's participation.

After applying the above actions in the classroom and by the results obtained from the observation (see Table 7) on average 24 (54.5\%) students were participated per day. Among this on average $48.3 \%$ of them are Females and $50.8 \%$ were males. From this we can understand that by applying the above action strategies our student's inactivity were more changed.

\section{Conclusion}

In this study, the researcher found different factors that are directly related to the low classroom participation. As we have seen in the data presentation and analysis part of this study, most of our students are not participated in class. Based on this problem, the researcher had been devised different action strategies/interventions were taken like; Awareness creation for students, re-organized the group, providing different responsibility to all member of the group to reduce dependency, and monitoring and providing feedback. At the end of taking all the actions discussed above the research team observed considerable improvement on student's participation.

\section{Recommendations}

The research teams recommended that all department and colleges across the university should implement and improve the participation and achievement of their students through cooperative learning method and all the students should actively participate in cooperative learning to improve their knowledge and academic achievements.

\section{References}

Biggs, J. 2003. 'Changing University Teaching' In Teaching for Quality Learning at University London, 2nd Edition, Society for Research into Higher Education and Open University Press.

Oakley, B., Felder, R. M., Brent, R. and Elhajj, I. 2004. Turning Student Groups into Effective Teams In Journal of Student Centered Learning, Vol. 2, No. 1, New Forums Press

Johnson, D. W. and Johnson, R. T. 1985. Student-Student Interaction: Ignored but powerful, in 'Research', edited by, Howey, K. R. Journal of Teacher Education.

Kaufman, D. B. and Felder, R. M. 2000. 'Accounting for Individual Effort in Cooperative Learning Teams' Journal of Engineering Education, 89(2) 133-140.

Sewnet Tesfaye and Kassahun Berhanu 2015. Improving Students' Participation in Active Learning Methods:Group Discussions, Presentations And Demonstrations: A Case of Madda Walabu University Second Year Tourism Management Students. Journal of Education and Practice, Vol.6, No.22

Yosef Kasa. 2016, Improving Student's Participation in the Classroom in Chemistry Freshman Students at Assosa University: An Experimental Action Research. International Journal of Education, Culture and Society. Vol. 1, No. 1, pp. 5-10.

Major, C., and B. Palmer, (2001). “Assessing the Effectiveness of Problem-Based Learning in Higher Education: Lessons from the Literature,' Academic Exchange Quarterly, Vol. 5, No. 1.

Mugny, G., \& Doise, W. (1978). Socio-cognitive conflict and the structure of individual and collective performances. European Journal of Social Psychology, 8, 181-192.

Robyn. M., \& Adrian F. A, (2003). Cooperative learning: the social and intellectual outcomes of learning in groups. Rout ledge Falmer. New Fetter Lane, London EC4P 4EE.

Appendix I

Table: 1 -Background Information of the Respondents

\begin{tabular}{lllllll}
\hline Sex & No & \% & Age & $<\mathbf{1 8}$ & $\mathbf{1 9 - 2 4}$ & $\mathbf{2 5 - 2 9}$ \\
\hline Male & 18 & 45 & & 0 & 16 & 2 \\
Female & 22 & 55 & & 0 & 21 & 1 \\
\hline
\end{tabular}


Table: 2. Questionnaire on Students Perception in Cooperative Learning

\begin{tabular}{|c|c|c|c|c|c|c|c|c|c|c|c|}
\hline \multirow[t]{3}{*}{ No } & \multirow[t]{3}{*}{ Items } & \multicolumn{10}{|c|}{ Responses scale } \\
\hline & & \multicolumn{2}{|l|}{5} & \multicolumn{2}{|l|}{4} & \multicolumn{2}{|c|}{3} & 2 & \multicolumn{2}{|l|}{1} & \multirow[b]{2}{*}{$\%$} \\
\hline & & $\mathrm{n}$ & $\%$ & $\mathrm{n}$ & $\%$ & $\mathrm{n}$ & $\%$ & $\mathrm{n}$ & $\%$ & $\mathrm{n}$ & \\
\hline 1 & Students interest in cooperative learning & 25 & 62.5 & 13 & 32.5 & 1 & 2.5 & 1 & 2.5 & 0 & 0 \\
\hline 2 & $\begin{array}{l}\text { Students participation in cooperative } \\
\text { learning }\end{array}$ & 10 & 25 & 15 & 37.5 & 1 & 2.5 & 8 & 20 & 6 & 15 \\
\hline 3 & $\begin{array}{l}\text { Students sharing of different responsibility } \\
\text { in group at Different time }\end{array}$ & 21 & 52.5 & 12 & 30 & 3 & 7.5 & 0 & 0 & 4 & 10 \\
\hline 4 & $\begin{array}{l}\text { Receive feedback from instructors about } \\
\text { cooperative Learning group work }\end{array}$ & 15 & 40 & 14 & 35 & 7 & 17.5 & 3 & 7.5 & 0 & 0 \\
\hline 5 & $\begin{array}{l}\text { Students knowledge about importance of } \\
\text { cooperative Learning }\end{array}$ & 27 & 67.5 & 10 & 25 & 3 & 7.5 & 0 & 0 & 0 & 0 \\
\hline 6 & $\begin{array}{l}\text { Instructors support of cooperative learning } \\
\text { if necessary }\end{array}$ & 22 & 55 & 7 & 17.5 & 8 & 20 & 1 & 2.5 & 2 & 5 \\
\hline 7 & $\begin{array}{l}\text { Role of cooperative learning in improving } \\
\text { social interaction }\end{array}$ & 23 & 57.5 & 8 & 20 & 3 & 7.5 & 2 & 5 & 4 & 10 \\
\hline 8 & $\begin{array}{l}\text { Cooperative learning creates common } \\
\text { understanding among Students }\end{array}$ & 21 & $52 . .5$ & 11 & 17.5 & 4 & 10 & 0 & 0 & 4 & 10 \\
\hline 9 & $\begin{array}{l}\text { Students awareness of cooperative learning } \\
\text { practices }\end{array}$ & 14 & 35 & 6 & 15 & 17 & 42.5 & 2 & 5 & 1 & 2.5 \\
\hline 10 & $\begin{array}{l}\text { Students motivation to participating in } \\
\text { cooperative learning Fully (assignment \& } \\
\text { project work) }\end{array}$ & 18 & 45 & 13 & 32.5 & 5 & 12.5 & 1 & 2.5 & 3 & 7.5 \\
\hline 11 & $\begin{array}{l}\text { Cooperative learning creates positive inter- } \\
\text { dependence Among students in the class } \\
\text { room. }\end{array}$ & 14 & 35 & 12 & 30 & 7 & 17.5 & 2 & 5 & 5 & 12. \\
\hline
\end{tabular}

Table 3 Questionnaires on factors affecting the Participation of Students in cooperative Learning.

\begin{tabular}{llll}
\hline No & Items/ Factors & Number of students \\
\hline & & $\mathrm{n}$ & $\%$ \\
$\mathbf{1}$ & Lack of awareness about the benefits of cooperative learning & 8 & 20 \\
$\mathbf{2}$ & Lack of students motivation to work in group & 19 & 47.5 \\
$\mathbf{3}$ & Uncomfortable seating arrangement of students & 14 & 35 \\
$\mathbf{4}$ & Insufficient support and follow up from teachers & 6 & 15 \\
$\mathbf{5}$ & Lack of teachers motivation to use cooperative learning & 8 & 20 \\
$\mathbf{6}$ & Shortage of time given by instructors to deal with the given issue & 12 & 30 \\
$\mathbf{7}$ & Domination of some group members (higher achievers) & 13 & 32.2 \\
$\mathbf{8}$ & Dependence of lower achievers on higher achievers & 8 & 20 \\
$\mathbf{9}$ & Unequal sharing of work among group members & 22 & 55 \\
$\mathbf{1 0}$ & Lack of reinforcement by teachers & 8 & 20 \\
$\mathbf{1 1}$ & Problem of grouping/ Organization structure & 16 & 40 \\
$\mathbf{1 2}$ & Relating cooperative learning with politics & 19 & 47.5 \\
\hline
\end{tabular}


Table 4. Action plan

\begin{tabular}{|c|c|c|c|c|}
\hline No & Activities & $\begin{array}{l}\text { Role of students and } \\
\text { instructors }\end{array}$ & $\begin{array}{l}\text { Time } \\
\text { require }\end{array}$ & Expected out come \\
\hline$\overline{1}$ & $\begin{array}{l}\text { Creating awareness about } \\
\text { cooperative learning }\end{array}$ & $\begin{array}{l}\text { Instructor provides training } \\
\text { for students. } \\
\text { Student actively participate in } \\
\text { the training }\end{array}$ & $2: 00 \mathrm{hrs}$ & $\begin{array}{l}\text { All student have good } \\
\text { understanding about } \\
\text { cooperative learning }\end{array}$ \\
\hline 2 & $\begin{array}{l}\text { Reorganizing group } \\
\text { arrangement }\end{array}$ & $\begin{array}{l}\text { Instructor restructures the } \\
\text { organization of group } \\
\text { members based on } \\
\text { achievement. Student should } \\
\text { participate in new group. }\end{array}$ & $1: 00$ & $\begin{array}{l}\text { Well organized group will } \\
\text { be formed }\end{array}$ \\
\hline 3 & $\begin{array}{l}\text { Providing different roles for } \\
\text { each group members like } \\
\text { facilitator, note taker, leader, } \\
\text { observer, reporter, or tasks } \\
\text { specific to the topic }\end{array}$ & $\begin{array}{l}\text { Instructor develops } \\
\text { cooperative learning } \\
\text { activities, which comprises } \\
\text { different roles. Student should } \\
\text { perform their role }\end{array}$ & 2:00 & $\begin{array}{l}\text { Each group member will } \\
\text { feel responsible for his/her } \\
\text { roles }\end{array}$ \\
\hline 4 & $\begin{array}{l}\text { Plans lessons that decide on: } \\
\text { (a) objectives, (b) size of } \\
\text { groups (c) how to group } \\
\text { students, (d) group roles and } \\
\text { (e) materials needed. }\end{array}$ & $\begin{array}{l}\text { Instructors Prepare plan for } \\
\text { cooperative learning }\end{array}$ & $2: 00$ & $\begin{array}{l}\text { Prepared effective } \\
\text { cooperative learning plan }\end{array}$ \\
\hline 5 & $\begin{array}{l}\text { Present and clearly explain } \\
\text { the activities that will student } \\
\text { take parts to complete. }\end{array}$ & $\begin{array}{l}\text { Instructor should provide } \\
\text { clear direction and students } \\
\text { should follow the direction }\end{array}$ & & $\begin{array}{l}\text { Student will follow the } \\
\text { instruction properly }\end{array}$ \\
\hline 6 & $\begin{array}{l}\text { Monitor and assist as needed } \\
\text { by providing the task to be } \\
\text { performed }\end{array}$ & $\begin{array}{l}\text { Instructor provides the } \\
\text { necessary support. Student } \\
\text { should ask teacher when they } \\
\text { need }\end{array}$ & & $\begin{array}{l}\text { Each group will gain } \\
\text { sufficient support from } \\
\text { the instructor }\end{array}$ \\
\hline 7 & $\begin{array}{l}\text { Evaluate each group's } \\
\text { performance } \\
\text { /product }\end{array}$ & $\begin{array}{l}\text { Make ready themselves to } \\
\text { participate in activity and } \\
\text { done the assignment } \\
\text { cooperatively. }\end{array}$ & & $\begin{array}{l}\text { A high student active } \\
\text { participation }\end{array}$ \\
\hline
\end{tabular}

Table 6 participation of students before intervention

\begin{tabular}{llllllll}
\hline & \multicolumn{2}{l}{ Number of students participated } & \multicolumn{3}{l}{ Number of students not participated } & Remark \\
\cline { 2 - 7 } Days & Male & Female & Total & Male & Female & Total & \\
\hline Day 1 & 3 & 2 & 5 & 18 & 20 & 38 & $* 1$ absent \\
Day 2 & 5 & 3 & 8 & 16 & 20 & 36 & -- \\
Day 3 & 3 & 3 & 6 & 17 & 19 & 36 & $* * 2$ absent \\
Day 4 & 8 & 1 & 9 & 13 & 22 & 35 & -- \\
Day 5 & 6 & 2 & 8 & 15 & 21 & 36 & -- \\
\hline
\end{tabular}

Table 7 participation of students after intervention

\begin{tabular}{llllllll}
\hline & \multicolumn{4}{l}{ Number of students participated } & \multicolumn{4}{l}{ Number of students not participated } & Remark \\
\cline { 2 - 7 } Days & Male & Female & Total & Male & Female & Total & \\
\hline Day 1 & 8 & 8 & 16 & 13 & 15 & 28 & 18 \\
Day 2 & 13 & 12 & 25 & 8 & 9 & 21 & \\
Day 3 & 12 & 11 & 23 & 9 & 13 & 21 & 12 \\
Day 4 & 10 & 13 & 23 & 11 & 10 & \\
Day 5 & 18 & 14 & 32 & 3 & 9 & & \\
\hline
\end{tabular}

